Folia primat. 1963;1:I-IV

\title{
Contents, Vol. 1, 1963
}

\section{CURATORES}

J. BIEGERT, Zurich

W. C. OSMAN HILL, Atlanta, Ga.

H. HOFER, Frankfurt a. M.

J. PIVETEAU, Paris

A. H. SCHULTZ, Zurich D. STARCK, Frankfurt a. M. S. L. WASHBURN, San Francisco, Calif.

COLLABORATORES

E. L. BONE, Louvain

W. FIEDLER, Wien

H. J. HARLOW, Madison, Wis.

H. HEDIGER, Zurich

J. HÜRZELER, Basel

J. KÄLIN, Fribourg

J. R. NAPIER, London

A. REMANE, Kiel

W. L. STRAUS, Jr., Baltimore, Md.

H. ZAPFE, Wien

S. ZUCKERMAN, Birmingham

REDACTOR:

J. BIEGERT, Zurich

Vol. 1

1963

BASEL (Schweiz) S. KARGER NEW YORK

Alle Rechte, insbesondere das der Übe $\Gamma$ setzung in fremde Sprachen, vorbehalten.

Ohne ausdriickliche Genehmigung des Verlages ist es auch nicht gestattet, dieses Buch oder Teile daraus

auf photomechanischem Wege (Photokopie, Mikrokopie) zu vervielfältigen

(c)

Copyright 1963 by S. Karger AG, Basel

Printed in Switzerland by Schellenberg-Druck, Pfäffikon ZH

Cliches: Steiner \& Cie. AG, Basel, und Aberegg-Steiner \& Cie. AG, Bern

INDEX

Preface - Vorwort - Preface

Bert, J. et Collomb, H.: 
Etude électroencéphalographique de deux cynomorphes de

Touest africain 137

Blitz, J.: vide Ploog, D. W.

Buettner-Janusch, J.:

Hemoglobins and Transferrins of Baboons

Chiarelli, B.:

Sensitivity to P.T.C. (Phenyl-Thio-Carbamide) in Primates .

Collomb, H.: vide Bert, J.

Davis, P. R. and Napier, J.:

A Reconstruction of the Skull of Proconsul africanus (R. S. 51)

Day, M. H. and Napier, J.:

The Functional Significance of the Deep Head of Flexor poll-icis brevis in Primates 122

DeVore, I. and Lee, R.:

Recent and Current Field Studies of Primates

Kuhn, H.-J.:

Ein angeborener Unterkieferdefekt bei Procolobus badíus badius (Kerr, 1792) 172

Kummer, H. and Kurt, F.:

Social Units of a Free-living Population of Hamadryas Baboons

Kurt, F.: vide Kummer, H.

Lange, V. und Schmitt, J.:

Das Serumeiweißbild der Primaten unter besonderer Berücksichtigung der Haptoglobine und Transferrine 208

Lee, R.: vide DeVore, I.

Napier, J.: vide Davis, P. R.

Napier, J.: vide Day, M. H.

Ploog, D. W.; Blitz, J. and Ploog, F.:

Studies on Social and Sexual Behavior of the Squirrel Monkey

(Saimirí sciureus)

29

Ploog, F.: vide Ploog, D. W.

Reynolds, V.:

An Outline of the Behaviour and Social Organization of Forestliving Chimpanzees

95

Schmitt, J.: vide Lange, V.

Schultz, A. H.:

Relations Between the Lengths of the Main Parts of the Foot

Skeleton in Primates 150

Tigges, J.: On Color Vision in Gibbon and Orang-utan

Vandenbergh, J. G.:

Feeding, Activity and Social Behavior of the Tree Shrew,

Tupaia glis, in a Large Outdoor Enclosure 199

Vogel, Ch. :

Sulcus mylohyoideus, Foramen mandibulae and Sulcus retrotoralis bei Ponginen und Hylobatiden 103

Zapfe, H.: 
Lebensbild von Megaladapís edwardsí (Grandidier). Ein Rekonstruktionsversuch 178

Current Literature - Neue Literatur - Nouveautes - 1962 . . 135, 251 